\title{
PEMANFAATAN LINGKUNGAN SEKITAR SEBAGAI MEDIA PEMBELAJARAN
}

\author{
Afan Chrislando*
}

\begin{abstract}
The lack of use of the surrounding environment as a learning media for students, where the teacher always considers that the only media or source of learning, but can be seen from the explanation of the theory, that the environment around children, a lot of information or symptoms that participants get not only students. The teacher can also feel the benefits of using the surrounding environment as a learning medium, can help teachers in delivering material that does not only occur in the classroom, but learns outside the classroom, and uses the environment as a source of learning, will make students know more about the environment around students.
\end{abstract}

Keywords: environment as a source of learning, learning media, students

\section{PENDAHULUAN}

Lingkungan merupakan sumber belajar yang banyak manfaat terhadap proses pembelajaran yang berlangsung. Lingkungan merupakan bagian dari manusia khususnya bagi peserta didik untuk hidup dan berinteraksi dengan sesamanya. Lingkungan yang ada disekitar anak-anak merupakan salah satu sumber belajar yang dapat digunakan dalam proses pembelajaran. Apabila seorang guru mengajar dengan memanfaatkan lingkungan sebagai sumber belajar maka akan lebih bermakna karena para siswa dihadapkan pada kenyataan dan peristiwa yang sebenarnya.

Menurut Sudjana (2010: 16) segala macam sumber yang ada di luar diri seseorang (peserta didik) dan yang memungkinkan atau memudahkan terjadinya proses pembelajaran disebut sebagai sumber belajar. Dalam pembelajaran guru harus bisa meningatkan daya berfikir kritis peserta didik, agar peserta didik lebih aktif, agar peserta didik bisa aktif guru harus mampu merancang pembelajaran yang bisa membuat peserta didik lebih aktif.

*) Pendidikan Guru Sekolah Dasar, FKIP, Universitas Kristen Satya Wacana E-mail: Chrislando12@gmail.com 
Kenyataanya masih banyak guru-guru menggunakan metode mengajar yang bersifat ceramah, dengan menggunakan metode pembelajaran ceramah, peserta didik lebih cepat merasa bosan didalam setiap pembelajaran dengan seperti ini peserta didik cepat merasa bosan berada didalam ruangan kelas dengan seperti ini proses belajar mengajar tidak efektif lagi karena peserta didik lebih asik sendiri, bermain dengan teman sebanguknya dan tidak memperhatikan gurunya saat penyampian materi didepan kelas.

Guru sudah berusaha menyampaikan materi dengan baik, dengan suara yang jelas, menatap semua siswa dan menegur siswa jika tidak memperhatikan. Upaya guru ini belum berhasil memotivasi siswa untuk mengikuti pembelajaran dengan serius. Siswa merasa bosan dengan metode ceramah yang digunakan oleh guru selama ini. Hal tersebut menjadi salah satu faktor penyebab hasil belajar yang kurang optimal.

Dengan begitu guru bisa mencoba untuk melakukan pembelajaran diluar ruangan dengan cara memanfaatkan lingkungan sekitar sebagai media belajar peserta didik, manfaat dari pembelajaran dengan melihat lingkungan sekitar peserta didik lebih bisa memahami apa saja yang ada dilingkungan sekitarnya, peserta didik bisa lebih banyak belajar dengan cara mengamati yang lingkungan yang ada di sekitarnya, peserta didik lebih aktif dan tidak cepat merasa bosan apabila mereka bisa langsung mengamati dengan sendirinya, peserta didik tidak hanya belajar melalui teori-teori tetapi mereka bisa belajar secara langsung dengan melihat lingkungan sekitarnya.

Berdasarkan latar belakang yang telah dikemukakan maka, rumusan masalah dalam penelitian ini adalah, bagaimana cara memanfaatkan lingkungan sekitar sebagai bahan belajar peserta didik. Sesuai dengan rumusan masalah maka tujuan penelitian ini adalah untuk mengetahui bahwa manfaat lingkungan sekitar bisa sebagai bahan belajar peserta didik.

Manfaat penelitian ini adalah memberikan pengalaman belajar yang lebih konkret dan langsung, menyajikan sesuatu yang tidak mungkin diadakan, dikunjungi, atau dilihat secara langsung, dapat menambah dan memperluas cakrawala sains yang ada di dalam kelas, memberikan informasi yang akurat dan terbaru, membantu memecahkan masalah pendidikan dalam lingkup makro maupun mikro, memberikan motivasi positif, merangsang untuk berfikir kritis, merangsang untuk bersikap lebih positif serta berkembang lebih jauh.

\section{Lingkungan Sebagai Sumber Belajar}

Menurut Andi Ikhsan, Sulaiman, Ruslan (2017:6) Pemanfaatan lingkungan sebagai sumber belajar dapat dilakukan dalam rangka 
mengembangkan potensi peserta didik, untuk melakukan kegiatan di luar kelas untuk menemukan sebab-sebab sebuah kejadian di sekitarnya, serta mencari hubungan antara fakta-fakta yang ada di lingkungan fisiknya seperti pencemaran sungai dengan pola hidup masyarakat di sekitarnya dan pelaksanaan peraturan atau kepatuhan hukum

1. Sumber masyarakat

Pemanfaatan masyarakat sebagi sumber belajar peserta didik akan memperjelas keterkaitan antara materi pembelajaran dengan fakta-fakta, atau peristiwa-peristiwa yang terjadi di lingkungan masyarakat. Sumber pembelajaran masyarakat akan memberikan pengalaman-pengalaman baru dan langsung kepada siswa dalam arti yang sebenarnya sehingga mendorong siswa untuk belajar lebih giat.

Di jelaskan oleh Sudjana (2010:208), lingkungan memiliki keuntungan sebagai berikut:

a. kegiatan belajar lebih menarik dan tidak membosankan siswa duduk di kelas berjam-jam, sehingga, motivasi belajar siswa akan lebih tinggi.

b. hakikat belajar akan lebih bermakna sebab siswa dihadapkan dengan situasi dan keadaan yang sebenarnya atau bersifat alami.

c. Bahan-bahan yang dapat dipelajari lebih kaya serta lebih faktual sehingga kebenarannya lebih akurat.

d. Kegiatan belajar siswa lebih komprehensif dan lebih aktif sebab dapat dilakukan dengan berbagai cara seperti mengamati, bertanya atau wawancara, membuktikan atau mendemonstrasikan, menguji fakta, dan lain-lain.

e. Sumber belajar menjadi lebih kaya sebab lingkungan yang dapat dipelajari bisa beraneka ragam seperti lingkungan sosial, lingkungan alam, lingkungan buatan, dan lain-lain.

f. Siswa dapat memahami dan menghayati aspek-aspek kehidupan yang ada di lingkungannya, sehingga dapat membentuk pribadi yang tidak asing dengan kehidupan di sekitarnya, serta dapat memupuk cinta lingkungan.

Menurut Kosasih (2014), lingkungan sebagai media pembelajaran dapat dibedakan antara lain (1) lingkungan alam, (2) lingkungan sosial dan (3) lingkungan budaya. Lingkungan alam, sosial dan budaya di sekitar sekolah merupakan sumber daya yang sangat kaya untuk bahan belajar siswa. Salah satu pemanfaatan lingkungan di sekolah dengan pengaturan lingkungan kelas yang dapat menumbuhkan semangat dan motivasi siswa. Pengaturan kelas yang 
baik akan memudahkan mewujudkan tujuan pembelajaran, misalnya bisa dirancang semenarik mungkin dengan gambar, warna dan tulisan-tulisan yang memenuhi rasa etika dan konsep yang jelas. Selain penggunaan media lingkungan kelas, belajar di luar kelas dan memanfaatkan lingkungan sekitar akan mampu menggugah semangat belajar siswa dan menunjang tercapainya tujuan pembelajaran yang maksimal.

Menurut Anggra Lita Sandra Dewi, Ery Rahmawati (2018:43). Penggunaan lingkungan sebagai sumber belajar, akan memberikan pengetahuan yang nyata bagi siswa. Kebiasaan untuk memanfaatkan fasilitas yang tersedia di lingkungan sekitar dalam proses belajar mengajar merupakan wujud proses belajar mengajar. Pemanfaatan lingkungan sebagai sumber belajar akan mempermudah siswa menyerap bahan materi pelajaran, lebih mengenal kondisi lingkungannya, menerapkan pengetahuan dan keterampilan yang dipelajarinya, serta akrab dengan lingkungannya.

Erviana (2015) menyebutkan bahwa, memanfaatkan lingkungan sebagai media pembelajaran memiliki beberapa keunggulan antara lain (1) menghemat biaya, (2) memberikan pengalaman yang nyata kepada siswa, (3) karena bendabenda tersebut berasal dari lingkungan siswa, maka benda-benda tersebut akan sesuai dengan karakteristik dan kebutuhan siswa, (4) pelajaran lebih aplikatif, (5) memberikan pengalaman langsung kepada siswa, (6) lebih komunikatif.

\section{METODE PENELITIAN}

Penelitian ini menggunakan pendekatan kuantitatif. Dengan menggunakan teori-teori dari para ahli dan dijabar kembali. Penelitian ini bertujuan agar guru bisa memanfaatan lingkungan sekitar sebagai media pembelajaran peserta didik agar peserta didik mendapatkan pengetahuan yang luas.

\section{HASIL DAN PEMBAHASAN}

(Sardiman, 2011:22-24), Media pembelajaran lingkungan adalah pemahaman terhadap gejala atau tingkah laku tertentu dari objek atau pengamatan ilmiah terhadap sesuatu yang ada di sekitar sebagai bahan pengajaran peserta didik sebelum dan sesudah menerima materi dari sekolah dengan membawa pengalaman dan penemuan dengan apa yang mereka temui di lingkungan sekitar.

Melalui pemanfaatan lingkungan sebagai media belajar, kemungkinan besar pemanfaatan lingkungan dapat diaplikasikan langsung, peserta didik akan menemui benda, media lingkungan memberikan pengalaman langsung kepada 
peserta didik, karena lingkungan secara alami mendorong anak untuk berinteraksi dengan komponennya, seperti dengan tumbuhan, hewan, atau manusia, dan benda mati di sekitar lingkungan.

Adanya interkasi secara langsung dengan lingkungan dalam pembelajaran akan memberikan dampak positif pada proses pembelajaran, peserta didik yang pasif selama pembelajaran biasanya akan lebih terlibat dalam proses pembelajaran saat terjun ke lingkungan. Contoh saat peserta didik mempelajari pengolahan sampah di lingkungan sekolah secara langsung, peserta didik bisa membedakan macam-macam sampah di lingkungan yang ada, maka akan dapat menumbuhkan rasa cinta terhadap kebersihan.

Dengan cara memanfaatkan lingkungan sekolah sebagai media belajar peserta didik, melalui kegiatan: penanaman dan penghijauan, mengaplikasikan teknik reproduksi buatan, membuat pupuk kompos dari sampah yang terdapat di sekolah, tata kelola lingkungan, budidaya tanaman, ciri tanaman/hewan, dan komponen ekosistem. Dengan pembelajaran seperti ini peserta didik akan dapat menumbuhkan rasa cinta terhadap kebersihan di lingkungan sekolah atau lingkungan tempat tinggal.

Dengan memanfaatkan lingkungan sebagai media pembelajaran, banyak manfaat bagi peserta didik maupun guru itu sendiri, peserta didik lebih banyak mendapatkan pengetahuan yang sangat luas, peserta didik bisa banyak belajar dengan cara mengamati lingkungan sekitar dengan secara langsung, peserta didik bisa melihat fenomena-fenomena apa saja yang terjadi dilingkungan sekitar mereka (Peserta didik).

Dalam penelitian ini dapat dilihat dari penjelasan diatas bawah memanfaatkan lingkungan sebagai media pembelajaran sangatlah besar keuntungan bagi guru maupun peserta didik. Keuntungan memanfaatkan lingkungan sebagai media belajar peserta didik, salah satunya menghemat biaya, karena dengan memanfaatkan benda-benda yang telah ada di lingkungan sekitar, yaitu praktis dan mudah dilakukan, tidak memerlukan peralatan khusus, memberikan pengalaman yang rill kepada peserta didik, pelajaran menjadi lebih konkrit, karena pembelajaran menggunakan benda-benda yang berasal dari lingkungan yang ada di sekitar peserta didik, maka benda-benda tersebuat yaitu akan sesuai dengan karakteristik dan kebutuhan peserta didik.

Pemilihan lingkungan sekitar sebagai media pembelajaran untuk sumber belajar dan sarana belajar bagi peserta didik dengan tetap mengacu pada lingkungan sekitar sebagai media pembelajaran serta tugas perkembangan peserta didik sehingga penggunaan dan pemanfaatan media pembelajaran dapat 
memperoleh hasil optimal media membantu dan mempermudah proses pembelajaran peserta didik diantaranya:

a. Pengalaman lansung yaitu peserta didik berhubungan lansung dengan objek yang di pelajari tampa menggunakan perantara.

b. Observasi yaitu pengalaman peninjauan secara cermat yang di lakukan oleh peserta didik.

c. Partisipasi pengalaman yang di peroleh melalui situasi kegiatan menggunakan skenario yang sesuai dengan tujuan pembelajaran.

Guru dengan mudah melakukan penyampian materi pembelajaran dengan mengkaitkan materi pembelajaran dengan lingkungan yang ada disekitar peserta didik, dengan begitu guru sangat tepat dalam cara penyampian materi apabila mencontohkan langsung teori yang ada dengan lingkungan disekitar peserta didik, apabila guru tidak memanfaatkannya dengan sebaik-baik mungkin, tentunya pembelajaran tidak banyak berguna dalam mencapai sebuah tujuan pembelajaran, agar pemanfaatan lingkungan sebagai media pembelajaran berjalan dengan efektif, pembelajaran harus direncanakan dan dirancang dengan sebaik-baik mungkin secara sistematik. Media pembelajaran sebagai sarana untuk mengembangkan keterampilan, mengeratkan hubungan dengan lingkungan, mengembangkan pengalaman dan pengetahuan siswa.

\section{SIMPULAN}

Pemanfaatan lingkungan sekitar sebagai media pembelajaran, dengan cara menggunakan benda-benda yang ada di lingkungan sekolah, akan dapat membantu lancarnya proses belajar mengajar di kelas maupun diluar kelas. Apabila pendidik bisa menggunakan dengan cara penyampian dengan tepat dan benar maka proses penyampaian materi akan tercapai dengan baik, mengenai cara pemanfaatan lingkungan sekitar sebagai media pembelajaran.

\section{DAFTAR PUSTAKA}

Andi Ikhsan, s. r. (2017). Pemanfaatan Lingkungan Sekolah sebagai Sumber Belajar di SD. Jurnal Ilmiah Pendidikan Guru Sekolah Dasar F KIP Unsyiah, 6 .

Anggra Lita Sandra Dewi, e. r. (2018). Peningkatan Hasil Belajar Siswa Melalui Pemanfaatan Lingkungan Sebagai Sumber Belajar. Elementary School Education Journal Volume 2 Nomor 2, 43. 
E, K. (2014). Strategi Belajar dan Pembelajaran Implementasi Kurikulum 2013. bandung: Yrama Widya.

Erviana, 1. (2015). Pemanfaatan Media Pembelajaran Berbasis Lingkungan sebagai Sarana Pratikum Ipa. jurnal dinamika pendidikan dasar volume 7 nomor 2.

Sardiman, A. (2011). Media Pembelajaran. Jakarta: rajawali pers. Sudjana. (2010). Media Pembelajaran. Bandung: Sinar Baru Algensido.

Pantiwati, Y. (2015). Pemanfaatan Lingkungan Sekolah sebagai Sumber Belajar dalam Lesson Study untuk Meningkatkan Metakognitif. Jurnal BIOEDUKATIKA, 28. 